\title{
Growth Evaluation of Native Chicks on Different Type of Hen Body Weight
}

\author{
Sutopo, E. Kurnianto, Sutiyono, E. T. Setiatin, Y. S. Ondho, D. A. Lestari, A. Setiaji, A. \\ Suryawijaya dan D. Samsudewa
}

Department of Animal Science, Faculty of Animal and Agricultural Sciences, Universitas Diponegoro Corresponding Author: daudreproduksi@gmail.com

\begin{abstract}
This research aims to measure the effect of hen body weight on the growth rate of native chicks. Ten native hens divided by two classifications (heavy and light body weight), 2 native roosters, 58 (from hen with heavy body weight), and 62 (from hen with light bodyweight) female day-old chicks (DoC) use in this research. Hatching machine, communal cage, feeder tray, drinking jar, balance body weight, and vernier caliper, were used in this research. Bodyweight and morphometric of female native chicken from DoC up to 10 weeks were measured. Ttest analysis was used with help of SPSS 25 . The results showed that the hen with heavy bodyweight resulted in the higher morphometric and bodyweight of female native chicken $(\mathrm{P}<0.05)$ on 7 and 8 weeks, respectively. The growth rate gain of female native chicken hatched by the hen with heavy body weight is significantly different $(\mathrm{P}<0.05)$ on body weight. The conclusion is the hen with heavy body weight will result in the higher body weight and morphometric of female native chicken.
\end{abstract}

Keywords: Growth evaluation, native chicks, different types of hen body weight

\section{INTRODUCTION}

Native chicken is the common chicken found in all islands of Indonesia. The flavored and healthier meat causes the Indonesian people to prefer to choose meat of native chicken as a table dish (Sutiyono et al., 2021). Unfortunately, the native chicken has low uniformity of body size (Malik et al., 2013). The uniformity of native chicken is affected by feed consumption, climate condition, and also genetics (Mavi et al., 2019). The low uniformity of chicken will affect to production and reproduction.

In the part of genetics, low uniformity has been caused by the poor selection program of native chicken (Zen et al., 2020). Increasing uniformity of native chicken can be done by a selection program (Rajkumar et al., 2021). The uniformity of chicken is connected to the genetic of rooster and hen. The hen body weight as a producer of eggs and day-old chick is one of the factors that affected the growth rate of the chicks (Mohammadifar and Mohammadabadi, 2017). The body weight and body score of a hen are connected to the nutrient supply to the fetus development in eggs (Wu et al., 2004).

The bodyweight of a hen can be separated by heavy and light bodyweight in one population. The hens with heavy body weight have a higher chance to produce chicken with a high growth rate. It was connected to the thyroid hormone function (Tan et al., 2014) The research about the effect of hen body weight on the growth of native chicken is not done yet. This research aims to measure the effect of hen body weight on the growth rate of native chicken.

\section{MATERIALS AND METHODS}

Ten native hens divided by two classifications with average body weight $1328 \pm$ $128 \mathrm{~g}$ for hens with heavy bodyweight and 1062 $\pm 192 \mathrm{~g}$ for a hen with light body weight, were used in this research. Two native roosters with an average body weight of $2382 \pm 208 \mathrm{~g}$ were also used in this research. Fifty-eight (from hen with heavy body weight) and 62 (from hen with light body weight) female day-old chicks (DoC) were used in this research. Hatching machine with a capacity of 500 eggs, communal cage, feeder tray, drinking jar, balance body weight (range of $2 \mathrm{~kg}$ and sensitivity $0.001 \mathrm{~kg}$ ), vernier caliper (range of $15 \mathrm{~cm}$ and sensitivity $0.01 \mathrm{~cm}$ ), were use in this research.

The native hen was mate by a rooster and the egg was collected for two periods of lying. The eggs were set on a hatching machine for 21 days. Pull chick was done and followed by sexing DoC to choose the female day-old chick. The female DoC was rearing for ten weeks. Every week the chicken was measured for body weight (BW), femur length (FL), tibia length, and sternum length (StL). The body weights were measured using the balanced body weight. Femur, tibia, and sternum length was measured using a vernier caliper. The body parts were measured shown in figure 1. 


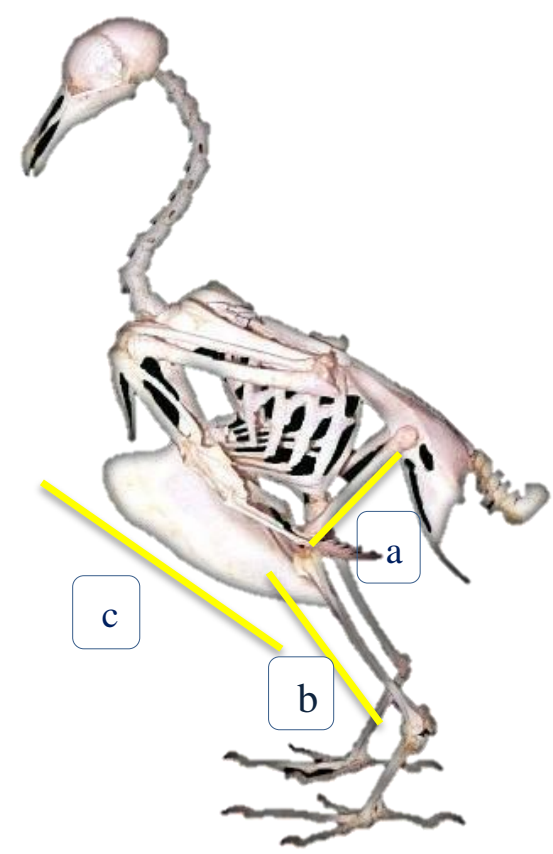

Figure 1. Part of the chicken body measured in this research (a) femur length; b (tibia length) and (c) sternum length

The t-test analysis was used to compare the parameters between the heavy and light bodyweight of a hen. Statistical Product and Service Solution (SPSS 25) was used for data analysis.

\section{RESULTS AND DISCUSSION}

Body Weight and Morphometric of Female Native Chicken from DoC up to 10 weeks

The result of this research is showed the Native chicken body weight and morphometric of DoC up to 10 weeks. The morphometric were measured are femur, tibia, and sternum length. The result showed in table 1.

T-test statistical analysis for the bodyweight of heavy and light hens of native chicken showed significantly different $(\mathrm{p}<0.05)$ on 8,9 , and 10 weeks. This result showed that the hens with heavy body weight will result in the higher body weight of the chicken. The higher body weight of chicken produced by a hen with heavy body weight is connected with the heritability of native chicken body weight. Faruque et al. (2013) stated that the heritability of Bangladesh native chicken for bodyweight on 12 weeks showed 0.73 . The heritability of native chicken bodyweight is connected with the gene that is expressed to the thyroxin hormone production.

Thyroxin is the hormone that responds to growth and muscle development. Increasing growth and muscle development will affect body weight. The research on Isfahan chicken has shown that the gene that has responded to the production of thyroxin hormone is connected to the chicken body weight (Izadnia et al., 2019). The bodyweight of native chicken on 8 weeks in this research is lower than the bodyweight of native chicken in Papua (600 g), KUB Chicken $(451.3 \mathrm{~g})$, and Sentul female chicken $(615.28 \mathrm{~g})$ (Rahayu et al., 2010; Urfa et al., 2017 and Gultom et al., 2021). This result is connected with the genetic quality of the chicken. The crossbreed of native chicken has a higher growth rate compared to the native chicken (Rahayu et al., 2010; Lestari et al., 2020).

Table 1. Body weight, tibia length, femur length and sternum length of native chicken 0-10 weeks

\begin{tabular}{|c|c|c|c|c|c|c|c|c|}
\hline \multirow{3}{*}{ Weeks } & \multicolumn{4}{|c|}{ Heavy Weight } & \multicolumn{4}{|c|}{ Light Weight } \\
\hline & BW & TL & FL & StL & BW & $\mathrm{TL}$ & FL & StL \\
\hline & $\mathrm{g}$ & ....... & $\mathrm{cm}$. & $\ldots \ldots$ & $\mathrm{g}$ & & $m \ldots \ldots$ & $\ldots$. \\
\hline 1 & 30.21 & 2.92 & 1.98 & 2.19 & 29.82 & 2.90 & 1.95 & 2.16 \\
\hline 2 & 67.42 & 3.64 & 2.50 & 2.69 & 66.62 & 3.61 & 2.46 & 2.66 \\
\hline 3 & 109.68 & 4.46 & 3.04 & 3.21 & 108.76 & 4.41 & 2.99 & 3.18 \\
\hline 4 & 152.95 & 5.30 & 3.60 & 3.77 & 152.48 & 5.27 & 3.55 & 3.73 \\
\hline 5 & 201.15 & 6.15 & 4.17 & 4.36 & 197.72 & 6.09 & 4.12 & 4.30 \\
\hline 6 & 252.39 & 7.02 & 4.76 & 4.98 & 246.93 & 6.96 & 4.70 & 4.90 \\
\hline 7 & 308.89 & $7.91^{\mathrm{a}}$ & $5.42^{\mathrm{a}}$ & $5.66^{\mathrm{a}}$ & 301.36 & $7.84^{\mathrm{b}}$ & $5.33^{b}$ & $5.57^{\mathrm{b}}$ \\
\hline 8 & $369.11^{\mathrm{a}}$ & $8.83^{\mathrm{a}}$ & $6.14^{\mathrm{a}}$ & $6.38^{\mathrm{a}}$ & $360.59^{\mathrm{b}}$ & $8.75^{\mathrm{b}}$ & $6.04^{b}$ & $6.29^{\mathrm{b}}$ \\
\hline 9 & $430.33^{\mathrm{a}}$ & $9.77^{\mathrm{a}}$ & $6.88^{\mathrm{a}}$ & $7.17^{\mathrm{a}}$ & $419.04^{b}$ & $9.68^{\mathrm{b}}$ & $6.77^{b}$ & $7.07^{\mathrm{b}}$ \\
\hline 10 & $491.53^{\mathrm{a}}$ & $10.65^{\mathrm{a}}$ & $7.56^{\mathrm{a}}$ & $7.91^{\mathrm{a}}$ & $475.29^{b}$ & $10.56^{\mathrm{b}}$ & $7.44^{b}$ & $7.78^{b}$ \\
\hline
\end{tabular}

${ }^{a}$, b Different superscript showed siginificantly different $(\mathrm{P}<0.05)$ 
T-test statistical analysis for morphometric (femur, tibia, and sternum length) of heavy and light hens of native chicken showed significantly different $(\mathrm{p}<0.05)$ start at 7 weeks. The differences of morphometric between heavy and light bodyweight are connected with the heritability of native chicken. Fayeye et al., (2014) stated that heritability has a higher factor to the body weight and morphometric of chicken. The femur length of native chicken in this research is higher than the local chicken of Tanzania and is brown. The opposite, tibia and femur length of native chicken in the present research is shorter than local chicken of Tanzania and is brown. The femur and tibia length of hen of local chicken of Tanzania is $6.19 \pm 0.03 \mathrm{~cm}$ and $13.2 \pm 0.06 \mathrm{~cm}$, respectively (Guni et al., 2013). Femur, tibia, and sternum length of hen of Isa Brown is $5.87 \pm 0.99 \mathrm{~cm}, 11.51 \pm 1.19 \mathrm{~cm}$, and $12.12 \pm 1.18 \mathrm{~cm}$, respectively (Fayeye et al., 2014).

\section{Growth Rate of Female Native Chicken from DoC up to 10 weeks}

The result of this research is showed the growth rate of Native chicken based on body weight and morphometric (femur, tibia, and sternum length) of DoC up to 10 weeks. The results of this research for the growth of native chicken showed in illustrations 1,2,3, and 4 .

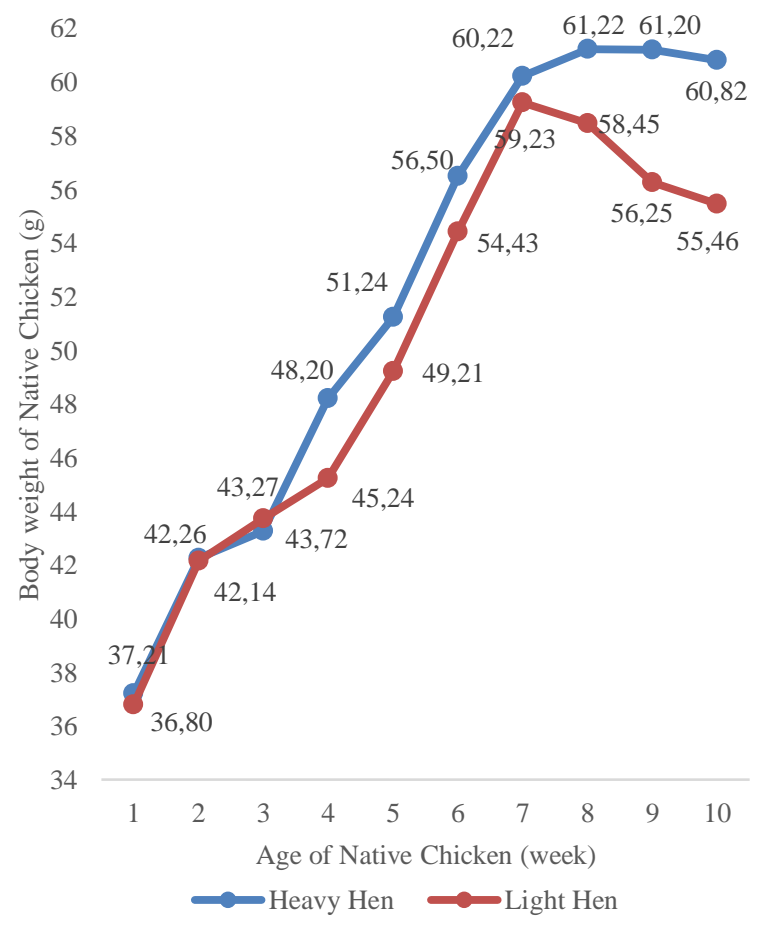

Graphic 1. Body weight gain of Native chicken of DoC up to 10 weeks.

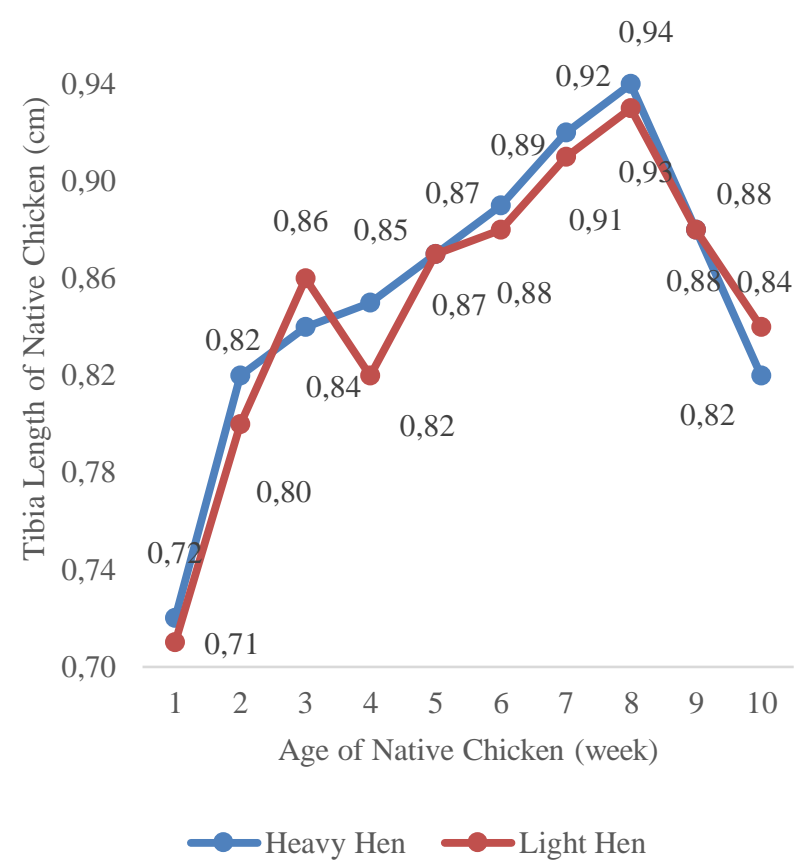

Graphic 2. Tibia Length Gain of Native chicken of DoC up to 10 weeks.

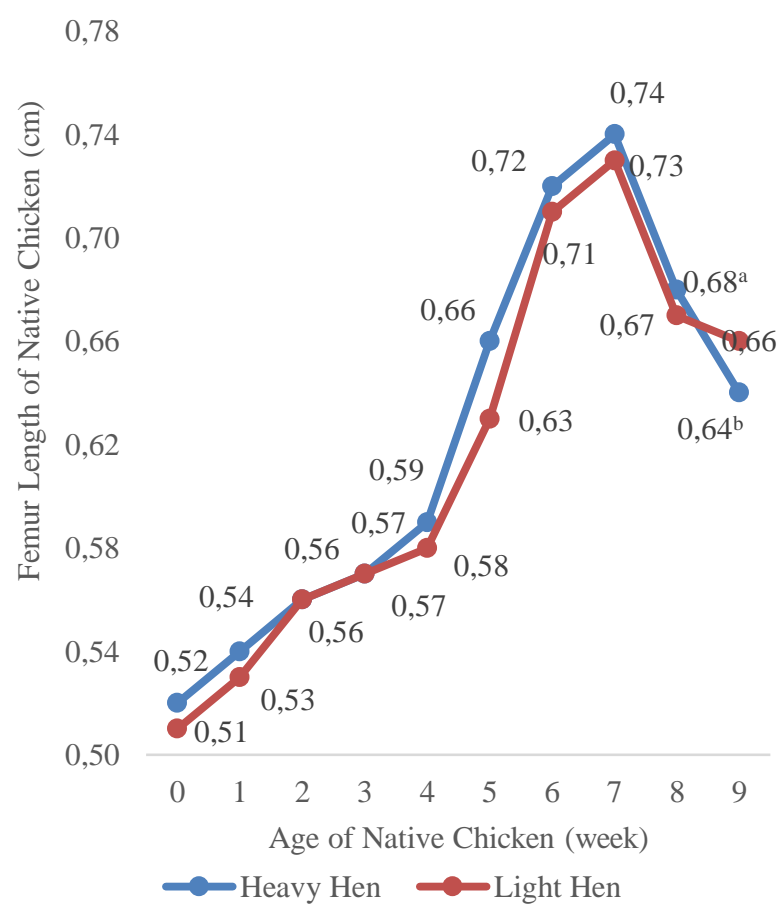

Graphic 3. Tibia length gain of native chicken of DoC up to 10 weeks.

a, bdifferent superscript showed siginificantly different $(\mathrm{p}<0.05)$ 


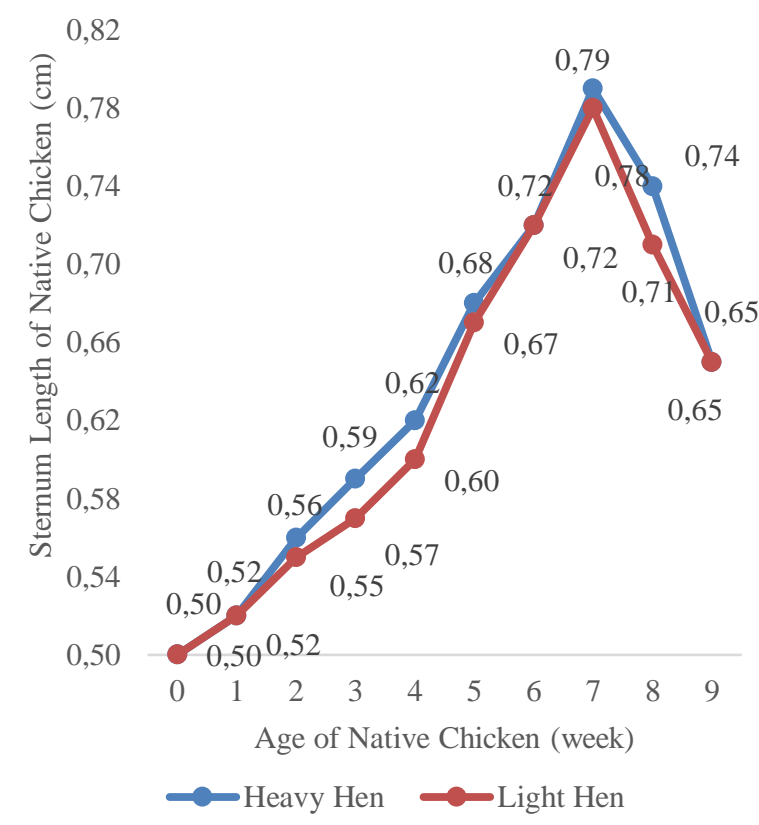

Graphic 4. Sternum length gain of Native chicken of DoC up to 10 weeks.

T-test statistical analysis for the body weight gain of female native chicken showed significant differences $(\mathrm{P}<0.05)$ starting at 8 weeks. On the other hand, t-test statistical analysis for morphometric is shown significant difference only $(\mathrm{P}<0.05)$ on 10 weeks of femur length gain. The other parameters and age of female native chicken showed non-significant different $(\mathrm{P} \geq 0.05)$. The present research showed that the growth rate of female native chicken fell start at 8 weeks for body weight and morphometric. It was the opposite with the research of Urfa et al., (2017) in KUB that still showed an increased growth rate of up to 12 weeks. This condition is related to the genetic potency of crossbreed chicken being haigher than the native chicken (Rahayu et al., 2010).

\section{CONCLUSION}

The conclusion is the hen with heavy body weight will result in the higher body weight and morphometric of female native chicken. The growth rate of DoC native chicken from a hen with heavy body weight is higher than the hen with a light body weight. The recommendation is Native chickens need to be selected to get the higher body weight and morphometric.

\section{ACKNOWLEDGMENT}

Thanks to the Rector of Universitas Diponegoro and Dean of Faculty of Animal and
Agricultural Sciences. Through research funding support based on the decree of Dean of Faculty of Animal and Agricultural Sciences Universitas Diponegoro Number. 43/UN7.5.5/PP/2019, this research can be done.

\section{REFERENCES}

Faruque, S., M. S. Islam, M. A. Afroz And M. M. Rahman. 2013. Evaluation Of The Performance of Native Chicken And Estimation Of Heritability For Body Weight. Journal Of Bangladesh Academy Of Sciences 37(1): 93-101. DOI: Https://Doi.Org/10.3329/Jbas.V37i1 .15685 .

Fayeye, T. R., J. K. Hagan and A. R. Obadare. 2014. Morphometric traits and correlation between body weight and body size traits in Isa Brown and Ilorin Ecotype chickens. IJAS, 4 (3) : 609-614. URL: http://ijas.iaurasht.ac.ir/article_513653.htm 1.

Gultom, L. H. M., G. Gushairiyanto and D. Depison. 2021. Correlation of Sentul chicken body weight at DoC age of 1, 2, and 3 months. Jurnal Sain Peternakan Indonesia $16 \quad$ (3): 273-276. DOI: https://doi.org/10.31186/jspi.id.16.3.273276.

Guni, F. S., A. M. Katule, and P. A. A. Mwakilembe. 2013. Characterization of local chickens in selected districts of the Southern Highlands of Tanzania: II. Production and Morphometric traits. Livestock Research for Rural Development 25 (11): 25-190. URL: http://www.lrrd.org/lrrd25/11/guni25190.h tm.

Izadnia, H. R., M. Tahmoorespur, M. R. Bakhtiarizadeh, M. Nassiri, and S. Esmaeilkhanien. 2019. Gene expression profile analysis of residual feed intake for Isfahan native chickens using RNA-SEQ data. Italian Journal of Animal Science 18 (1): 246-260. DOI: 10.1080/1828051X.2018.1507625.

Lestari, L., M. Maskur, R. Jan, T. Rozi, L. M. Kasip and M. Muhsinin. 2020. Studi karakteristik sifat kualitatif dan morfometrik induk ayam kampung dengan 
berbagai tipe jengger di pulau lombok. Jurnal Ilmu dan Teknologi Peternakan Indonesia 6 (1): 24-32. DOI: https://doi.org/10.29303/jitpi.v5i2.64

Malik, A., A. W. Haron, R. Yussof, M. Nesa, M. Bukar and A. Kasim. 2013. Evaluation of the ejaculate quality of the red jungle fowl, domestic chicken, and bantam chicken in Malaysia. Turk. J. Vet. Anim. Sci. 37: 564-568. DOI: 10.3906/vet-1107-26.

Mavi, G.K., P. P. Dubey, S. C. Ranjna, S. K. Dash and B, K, Bansal. 2019. Comparative analysis of semen quality parameters and their relationship with fertility in different genetic groups of layer chicken. Indian Journal of Animal Research 53 (10): 12691274. DOI: $10.18805 /$ ijar.B-3646.

Mohammadifar, A. and M.R. Mohammadabadi. 2017. The effect of uncoupling protein polymorphisms on growth, the breeding value of growth, and reproductive traits in the Fars indigenous chicken. IJAS 7 (4): 679-685.

URL: http://ijas.iaurasht.ac.ir/article_535799 .html.

Rahayu, B. W. I., A. E. Widodo and R. Saronggalo. 2010. Penampilan pertumbuhan ayam persilangan Kampung dan Bangkok. Jurnal Ilmu Peternakan 5 (2): 77-81. URL: 01 Jurnal Artikel.pdf (unipa.ac.id).

Rajkumar, U., L. L. L. Prince, K. S. Rajaravindra, S. Haunshi, M. Niranjan and R. N. Chatterjee. 2021. Analysis of (co) variance components and estimation of breeding value of growth and production traits in Dahlem Red chicken using pedigree relationship in an animal model. PloS ONE 16 (3): 1-21. DOI: https://doi.org/10.1371/journal.pone. 0247779 .

Sutiyono, E. Kurnianto, Sutopo, D. K. Ariyanto and D. Samsudewa. 2021. Evaluation of native rooster based on breeding value of trait of macroscopic and microscopic semen quality. Jurnal Sain Peternakan Indonesia. 16(3): 228-232. DOI: https://doi.org/10.31186/jspi.id. 16.3.228232.

Tan, J., S. Liu, Y. Guo, T. J. Applegate and S. D. Eicher. 2014. Dietary L-arginine supplementation attenuates lipopolysaccharide-induced inflammatory response in broiler chickens. Br. J. Nutr. 111: 1394-1404. DOI: 10.1017/S0007114513003863.

Urfa, S., H. Indrijani and W. Tanwiriah. 2017. Growth curve model of kampung unggul balitnak (KUB) chicken. Jurnal Ilmu Ternak 17(1): 59-66. DOI: https://doi.org/ 10.24198/jit.v17i1.14863.

Wu, G., F. W. Bazer, T. A. Cudd, C. J. Meininger and T. E. Spencer. 2004. Maternal nutrition and fetal development. J. Nutr. 134: 2169-2172. DOI: 10.1093/jn/134.9.2169.

Zen, A. A., Y. S. Ondho dan Sutiyono. 2020. Seleksi pejantan ayam kampung berdasarkan breeding value terhadap gerak massa, abnormalitas dan motilitas spermatozoa. JSPI 15 (3): 339-347. DOI: https://doi.org/10.31186/jspi.id.15.3.339347. 